\title{
Postmenopausal Osteoporosis
}

\author{
Vikram Khanna ${ }^{1 *}$, Parul Gupta ${ }^{2}$, Ranjana Khanna ${ }^{3}$ and Harish Chandra Khanna ${ }^{4}$ \\ ${ }^{1}$ Department of Orthopaedics, Ranjana Hospital, India \\ ${ }^{2}$ Department of OBGYN, Ranjana Hospital, India \\ ${ }^{3}$ Department of OBGYN, Ranjana Hospital, India \\ ${ }^{4}$ Department of Internal Medicine, Ranjana Hospital, India
}

Submission: December 10, 2016; Published: January 24, 2017

*Corresponding author: Vikram Khanna, Department of Orthopaedics, Ranjana Hospital, Allahabad, India, Tel: +91 9335106867;

Email: 86.khanna@gmail.com

Abstract

Osteoporosis is a condition with a very high prevalence and its spreading at a rapid pace which is in tandem with the increase in the life expectancy of the general population. With the change in the eating habits the patients are not getting adequate nutrition for the wellbeing of the bones. With the advancements in the field of bone mineral density measurement it may now be possible for early detection and rapid treatment which may lead to the better outcome for the patient and may prove less detrimental for the society as well.

Keywords: Osteoporosis; Menopause; BMD

\section{Introduction}

Osteoporosis is a silent condition which has been on the rise in the recent times due to the increase in the life expectancy of the patients [1]. This affects the physical, mental as well as socioeconomic condition of the patient. This review article summarizes the important aspects of this condition as well as sheds light on its treatment.

\section{Definition}

The working group of WHO in 1994 came up with the definition which was based on $\mathrm{T}$ score of the Bone mineral density (BMD) and it said that a T score less than -2.5 can be considered as osteoporosis [2].

\section{Background}

The number of patients with osteoporosis is on a rise and it is expected that the no. will soon reach 34 million in USA [3]. Out of which $80 \%$ are expected to be women. The incidence of osteoporosis increases exponentially with age and there is a sharp increase in cases following menopause in females. The incidence of osteoporosis is also associated with an increase in the incidence of fractures which also rises following the decrease in the bone mineral density [4].

\section{Pathophysiology of Postmenopausal Osteoporosis}

There may be 2 causes of postmenopausal osteoporosis a. Low peak bone mass

b. Increased bone loss, or both Peak bone mass is determined $70 \%-80 \%$ by genetic factors [5-8]. Remaining causative factors for the peak bone mass include factors like nutrition, activity and hormonal interplay.

Once the peak bone mass is achieved, bone regulation takes place by local remodeling which is regulated by RANK, RANKL protein and OPG. RANK or receptor activator of nuclear factor$\mathrm{kb}$ is present in the osteoclasts and causes the increase in their activity. RANKL or the RANK Ligand is synthetized by osteoblasts and it binds with the RANK receptor on the osteoclasts. OPG or Osteoprotegerin is also synthetized by the osteoblasts and prevents the binding of the RANK to the RANK Ligand by itself binding to the RANKL. Hence, the activity of the osteoclasts and in turn the bone remodeling depends upon the interplay between the RANK and the OPG. This interplay is controlled by hormonal and local factors. If the bone remodeling is in balance (osteoblast $=$ osteoclasts) then there is no decrease in the BMD. A change in the balance of remodeling causes the change in the BMD accordingly.

In postmenopausal females, there are hormonal changes which cause an increase in the RANKL which causes increase in the osteoclastic activity and hence, shifts the bone remodeling towards a bone resorbing balance which leads to osteoporosis. 


\section{Juniper Online Journal of Case Studies}

It has been noted that the bone loss is maximum 3-5 years before menopause and also 3-5 years after menopause. These points towards the indirect as well as the direct causes of bone loss leading to osteoporosis. This bone loss is faster than the average bone loss seen in the senile osteoporosis seen in males. There is also research going on which suggests the change in the micro architecture of bone with the advent of osteoporosis. However, this research and the quantification of these changes are still in experimental stages and not available for commercial use [9]. Factors which accelerate bone loss are included in Table 1. Also, factors which increase the risk of falling and fractures are included in Table 2 .

Table 1: Factors Accelerating bone loss.

\begin{tabular}{|c|}
\hline Factors Accelerating bone loss \\
\hline Endocrine disorders \\
\hline Hyperthyroidism \\
\hline Hypogonadism \\
\hline Cushing disease \\
\hline Gastrointestinal disorders \\
\hline Short bowel syndrome \\
\hline Hematologic disorders \\
\hline Multiple myeloma \\
\hline Renal disorders \\
\hline Renal failure \\
\hline Neuromuscular disorders \\
\hline Muscular dystrophy \\
\hline Paraplegia \\
\hline Quadriplegia \\
\hline Medications \\
\hline Corticosteroids \\
\hline Anti epilepsy drugs \\
\hline Medroxy progesterone acetate \\
\hline SSRI \\
\hline Excess vitamin A \\
\hline
\end{tabular}

Table 2: Factors increasing the risk of falling.

\begin{tabular}{|c|}
\hline Factors Increasing the Risk of Falling \\
\hline Neurologic disorders \\
\hline Parkinson disease \\
\hline Neuropathy \\
\hline Stroke \\
\hline Dementia \\
\hline Impaired balance \\
\hline Orthostatic hypotension \\
\hline Impaired vision or hearing \\
\hline Frailty \\
\hline Medications \\
\hline
\end{tabular}

\begin{tabular}{|c|}
\hline Sedatives and hypnotics \\
\hline Antihypertensive agents \\
\hline Environmental factors \\
\hline Poor lighting \\
\hline Wet, icy, or uneven pavement \\
\hline Uneven roads \\
\hline Electric cords \\
\hline Large pets \\
\hline Rugs \\
\hline
\end{tabular}

\section{Clinical Features of Postmenopausal Osteoporosis}

These include:

1. Low Bone mass: measured by BMD

2. Fracture: Single most important manifestation of postmenopausal osteoporosis.

Lifestyle and Non pharmacologic Measures for Bone Health

Goals of this therapy include:

a. Optimizing skeletal development to increase the peak bone mass

b. Prevent secondary bone loss

c. Preserve the skeletal structural integrity

d. Prevent fractures

Following diets should be taken into consideration:

1. Good general Nutrition: A balanced diet is necessary for the development of a good peak bone mass. The peak bone mass also depends upon the protein intake as well as the activity level of the patient [10-12].

Table 3: Daily Calcium Recommendation (mg/dl) for females 14.

\begin{tabular}{|c|c|}
\hline Age & $\begin{array}{c}\text { Daily Calcium Recommendation } \mathbf{( m g} / \mathbf{d l}) \text { for } \\
\text { Females14 }\end{array}$ \\
\hline 9-18yrs & 1300 \\
\hline 19-50yrs & 1000 \\
\hline 51-70yrs & 1200 \\
\hline 70yrs+ & 1200 \\
\hline
\end{tabular}

2. Calcium: The recommended dose of daily requirement of calcium in various situations is given in Table 3. Some points to be taken into consideration are that calcium is absorbed better with food and calcium citrate gives the least amount of GI side effects as compared to other calcium compounds.

3. Vitamin D: It is important to assess serum Vitamin D in all individuals suffering from osteoporosis. Vitamin D is found in food stuff like fish oils, fortified milk, cereals and breads. National Osteoporosis foundation recommends a 
dose of 800-1000 IU for patients more than 50 years old [13]. However, many experts feel that the dose should be between 1000-2000 IU (Safe upper limit being 4000IU/day) [14]. Currently the normal level is $30-32 \mathrm{ng} / \mathrm{ml}$ (Upper limit being $60 \mathrm{ng} / \mathrm{ml}$ ) [15]. Even though daily doses are present still it has been seen that the intermittent dose was found to be 3 times more potent [16].

4. Other dietary supplements: Magnesium doesn't increase the calcium absorption but decrease the GI side effects [17]. Excessive Vitamin A was harmful for the bones in large doses (more than 100000 IU) [18]. Vitamin K (1mg/ day) has been found to decrease the bone turnover and hence decrease the bone loss [19]. Natural estrogens (isoflavones) were thought to prevent bone loss but there has not been any scientific evidence for the same [20-22].

5. Alcohol: Excessive alcohol intake causes bone loss [23]. Postmenopausal women should take a maximum of 7 drinks a week.

6. Caffeine: Postmenopausal osteoporotic women should limit their caffeine intake less than 1-2 servings/day as it decreases the intestinal absorption of calcium [24].

7. Smoking: It is associated with osteoporotic fractures. Patients who give up smoking are at a lesser risk than those who are active smokers [25].

8. Exercise: Regular light exercises (30-40 mins) everyday increases the muscle strength and it has been seen that it also causes the bone strength to increase [26,27]. However patients with severe osteoporosis should avoid heavy exercises like lifting weights or excessive pushing or pulling.

Prevention of risk factors for Post-menopausal osteoporosis

1. Spine Imaging: to rule out any fractures

2. BMD: measured either at the spine or the neck of femur. It can be used to assess the probability of fracture in the next 10 years in a patient using the FRAX tool. However, this modality is still expensive and the benefit to the society is still not confirmed. Lists of indications have been summarized in Table 4.

Table 4: Indications for doing BMD.

\begin{tabular}{|c|}
\hline Indications for doing BMD \\
\hline Women $>65 \mathrm{y}$ \\
\hline Postmenopausal women \\
\hline H/o Fragility fractures after age $40 \mathrm{y}$ \\
\hline Osteopenia \\
\hline Long-term systemic glucocorticoid therapy \\
\hline Low body weight $(\mathrm{BMI}<20 \mathrm{~kg} / \mathrm{m} 2)$ \\
\hline
\end{tabular}

\begin{tabular}{|c|}
\hline Family H/o fragility fracture \\
\hline Early menopause \\
\hline Smoking \\
\hline Alcohol \\
\hline
\end{tabular}

\section{Treatment of Osteoporosis}

Candidates requiring treatment for osteoporosis include [28]:

1. Hip or spine fracture

2. T score $<-2.5$

3. T score between -1 to -2.5 with a probability of fracture as calculated by FRAX tool

Table 5: List of drugs approved for osteoporosis.

\begin{tabular}{|c|c|c|}
\hline & $\begin{array}{c}\text { Postmenopausal } \\
\text { Osteoporosis }\end{array}$ & \\
\hline Drug & Prevention & Treatment \\
\hline Estrogen & Multiple regimen & \\
\hline Calcitonin & & 200 IU intranasal OD \\
\hline Denosumab & & $60 \mathrm{mg} \mathrm{SC} \times 6$ mthly \\
\hline Raloxifene & $60 \mathrm{mg}$ OD & $60 \mathrm{mg}$ OD \\
\hline Ibandronate & $150 \mathrm{mg}$ mthly & $150 \mathrm{mg}$ mthly \\
\hline Alendronate & $35 \mathrm{mg}$ wkly & $70 \mathrm{mg}$ wkly \\
\hline Risendronate & $35 \mathrm{mg}$ wkly & $35 \mathrm{mg}$ wkly \\
\hline Zoledronic Acid & $5 \mathrm{mg}$ IV x 2 yrs & $5 \mathrm{mg}$ IV yrly \\
\hline Teriparatide & & $20 \mu \mathrm{g}$ SQ daily \\
\hline
\end{tabular}

Table 6: Evidence of fracture risk reduction.

\begin{tabular}{|c|c|c|}
\hline & \multicolumn{2}{|c|}{ Risk Reduction } \\
\hline Drug & Vertebral & Hip Fractures \\
\hline Calcitonin & Yes & No \\
\hline Denosumab & Yes & Yes \\
\hline Raloxifene & Yes & No \\
\hline Ibandronate & Yes & No \\
\hline Alendronate & Yes & Yes \\
\hline Risendronate & Yes & Yes \\
\hline Zoledronic Acid & Yes & Yes \\
\hline Teriparatide & Yes & No \\
\hline
\end{tabular}

Drugs approved for postmenopausal osteoporosis have been listed along with their dosage in Table 5 and their possible effects on fracture risk reduction have been mentioned in Table 6. Concomitant use of anti-osteoporotic drugs was thought to reduce the fracture risk better than using a single drug [29]. However, further studies have led to the non-recommendation of this practice [30]. The sequential use of drugs, first the anabolic group followed by the anti resorptive drugs has been found to be beneficial for patients [31]. 


\section{Juniper Online Journal of Case Studies}

\section{BMD in progression of the treatment}

BMD may be used for the prognosis and the follow-up of the treatment of osteoporosis. The treatment is said to have failed if there is substantial fall in the BMD or any fracture occurrence.

\section{Operative treatment for osteoporosis}

Most commonly occurring fractures are the vertebral fractures and there has always been a difference of opinion regarding the management of the same. Vertebroplasty though decreases the pain instantly but doesn't increase the vertebral height to normal whereas, Kyphoplasty increases the vertebral height along with the reduction in the pain but is expensive [3236]. The surgeon should be careful in the fixation of the other fractures by using locking plates and HA coated implants to provide a stable fixation.

\section{Conclusion}

The incidence of postmenopausal osteoporosis is on the rise and one should be careful in the management and suitable pharmacotherapy should be given which is tailor made for each and every patient.

\section{References}

1. Centers for Disease Control and Prevention (CDC) (2006) Fatalities and injuries from falls among older adults-United States, 1993-2003 and 2001-2005 MMWR Morb Mortal Weekly Rep 55(45): 1221-1224.

2. Kanis JA, Melton LJ III, Christiansen C, Johnston CC, Khaltaev N (1994) The diagnosis of osteoporosis. J Bone Miner Res 9(8): 1137-1141.

3. National Osteoporosis Foundation (2002) America's Bone Health: The State of Osteoporosis and Low Bone Mass in Our Nation. National Osteoporosis Foundation, Washington, USA.

4. Burge R, Dawson Hughes B, Solomon DH, Wong JB, King A, et al. (2007) Incidence and economic burden of osteoporosis-related fractures in the United States, 2005-2025. J Bone Miner Res 22(3): 465-475.

5. Brown LB, Streeten EA, Shapiro JR, McBride D, Shuldiner AR, et al. (2005) Genetic and environmental influences on bone mineral density in pre- and post-menopausal women. Osteoporos Int 16(12): 18491856.

6. Recker RR, Deng HW (2002) Role of genetics in osteoporosis. Endocrine 17(1): 55-66.

7. Williams F (2006) Genetic regulation of bone mass and susceptibility to osteoporosis. J Musculoskel Neuron Interact 6: 27-35.

8. Richards JB, Kavvoura FK, Rivadeneira F, Styrkársdóttir U, Estrada K, et al (2009) (Genetic Factors for Osteoporosis Consortium). Collaborative meta-analysis: associations of 150 candidate genes with osteoporosis and osteoporotic fracture. Ann Intern Med 151(8): 528-537.

9. Seeman E, Delmas PD (2006) Bone quality-the material and structural basis of bone strength and fragility. N Engl JMed 354(21): 2250-2261.

10. Misra M, Klibanski A (2006) Anorexia nervosa and osteoporosis. Rev Endocr Metab Disord 7(1-2): 91-99.

11. Rizzoli R, Ammann P, Chevalley T, Bonjour JP (2001) Protein intake and bone disorders in the elderly. Joint Bone Spine 68(5): 383-392.

12. Schürch MA, Rizzoli R, Slosman D, Vadas L, Vergnaud P, et al. (1998) Protein supplements increase serum insulin-like growth factor-1 levels and attenuate proximal femur bone loss in patients with recent hip fracture: a randomized, double-blind, placebo-controlled trial. AnnIntern Med 128(10): 801-809.
13. Dawson-Hughes B, Heaney RP, Holick MF, Lips P, Meunier PJ, et al (2005) Estimates of optimal vitamin D status. Osteoporos Int 16(7): 713-716.

14. Ross AC, Manson JE, Abrams SA, Aloia JF, Brannon PM, et al. (2011) The 2011 report on dietary reference intakes for calcium and vitamin D from the Institute of Medicine: what clinicians need to know. J Clin Endocrinol Metab 96(1): 53-58.

15. Binkley N, Novotny R, Krueger D, Kawahara T, Daida YG, et al. (2007) Low vitamin D status despite abundant sun exposure. J ClinEndocrinolMetab 92(6): 2130-2135.

16. Holick MF, Biancuzzo RM, Chen TC, Klein EK, Young A et al. (2008) Vitamin D2 is as effective as vitamin D3 in maintaining circulating concentrations of 25-hydroxyvitamin D. J Clin Endocrinol Metab 93(3): 677-681.

17. Spencer H, Fuller H, Norris C, Williams D (1994) Effect of magnesium on the intestinal absorption of calcium in man. J Am Coll Nutr 13(5): 485-492.

18. Jackson HA, Sheehan AH (2005) Effect of vitamin A onfracture risk. Ann Pharmacother 39(12): 2086-2090.

19. Braam LA, Knapen MH, Geusens P, Brouns F, Hamulyák K, et al. (2003) Vitamin K1 supplementation retards bone loss in postmenopausal women between 50 and 60 years of age. Calcif Tissue Int 73(1): 21-26.

20. Alexandersen P, Toussaint A, Christiansen C, Devogelaer JP, Roux C et al (2001) (Ipraflavone Multicenter European Fracture Study). Ipriflavone in the treatment of postmenopausal osteoporosis: a randomized controlled trial. JAMA 285(11): 1482-1488.

21. Atkinson C, Compston JE, Day NE, Dowsett M, Bingham SA (2004) The effects of phytoestrogen isoflavones on bone density in women: a double-blind, randomized, placebo-controlled trial. Am J ClinNutr $79(2): 326-333$.

22. Gallagher JC, Satpathy R, Rafferty K, Haynatzka V (2004) The effect of soy protein isolate on bone metabolism. Menopause 11(3): 290-298.

23. Kanis JA, Johansson H, Johnell O, Oden A, De Laet C, et al. (2005) Alcohol intake as a risk factor for fracture. Osteoporos Int 16(7): 737-742.

24. Hallström H, Wolk A, Glynn A, Michaëlsson K (2006) Coffee, tea and caffeine consumption in relation to osteoporotic fracture risk in a cohort of Swedish women. Osteoporos Int 17(7): 1055-1064.

25. Kiel DP, Felson DT, Hannan MT, Anderson JJ, Wilson PW (1990) Caffeine and the risk of hip fracture: the FraminghamStudy. Am J Epidemiol 132(4): 675-684

26. Snow-Harter C, Bouxsein M, Lewis B, Charette S, Weinstein P, et al. (1990) Muscle strength as a predictor of bone mineral density in young women. J Bone Miner Res 5(6): 589-595.

27. Snow-Harter C, Bouxsein ML, Lewis BT, Carter DR, Marcus R (1992) Effects of resistance and endurance exercise on bone mineral status of young women: a randomized exercise intervention trial. J Bone Miner Res 7(7): 761-769.

28. National Osteoporosis (2008) Foundation. Clinician's Guide to Prevention and Treatment of Osteoporosis. National Osteoporosis Foundation, Washington, USA.

29. Compston JE, Watts NB (2002) Combination therapy for postmenopausal osteoporosis. Clin Endocrinol (Oxf) 56(5): 565-569.

30. Black DM, Greenspan SL, Ensrud KE, Palermo L, McGowan JA, et al. (2003) The effects of parathyroid hormone and alendronate alone or in combination in postmenopausalosteoporosis. N Engl J Med 349(13): 1207-1215.

31. Watts NB, Harris ST, Genant HK, Wasnich RD, Miller PD, et al. (1990) Intermittent cyclical etidronate treatment of postmenopausal osteoporosis. N Engl J Med 323(2): 73-79. 
32. Anselmetti GC, Muto M, Guglielmi G, Masala S (2010) Percutaneous vertebroplasty or kyphoplasty. Radiol Clin North Am 48(3): 641-649.

33. Röllinghoff M, Zarghooni K, Dargel J, Schlegel UJ, Siewe J et al. (2010) The present role of vertebroplasty and kyphoplasty in the treatment of fresh vertebral compression fractures. Minerva Chir 65(4): 429-437.

34. Buchbinder R, Osborne RH, Ebeling PR, Wark JD, Mitchell P, et al. (2009) A randomized trial of vertebroplasty for painful osteoporotic vertebral fractures. N Engl J Med 361(6): 557-568.

This work is licensed under Creative

Commons Attribution 4.0 Licens
35. Kallmes DF, Comstock BA, Heagerty PJ, Turner JA, Wilson DJ, et al. (2009) A randomized trial of vertebroplasty for osteoporotic spinalfractures. N Engl J Med 361(6): 569-579.

36. Shindle MK, Gardner MJ, Koob J, Bukata S, Cabin JA, et al. (2006) Vertebral height restoration in osteoporotic compression fractures: kyphoplasty balloon tamp is superior to postural correction alone. Osteoporos Int 17(12): 1815-1819.

\section{Your next submission with Juniper Publishers will reach you the below assets}

- Quality Editorial service

- Swift Peer Review

- Reprints availability

- E-prints Service

- Manuscript Podcast for convenient understanding

- Global attainment for your research

- Manuscript accessibility in different formats

( Pdf, E-pub, Full Text, Audio)

- Unceasing customer service

Track the below URL for one-step submission

https://juniperpublishers.com/online-submission.php 